MARIA DĘBOWSKA* - LUBLIN

\title{
OBRAZ MATKI BOŻEJ LATYCZOWSKIEJ W DIECEZJI ŁUCKIEJ
} (1930-1945)

\section{Wprowadzenie}

Obraz Matki Bożej z Latyczowa podzielił losy Polaków, zmuszonych opuścić swoje miejsca rodzinne na kresach wschodnich I Rzeczypospolitej (Podole, Żytomierszczyzna, Kijowszczyzna) w wyniku wydarzeń będących pochodną rewolucji bolszewickiej w Rosji oraz wojny polsko-bolszewickiej w 1920 r. Proboszcz latyczowski ks. Franciszek Szymkus wywiózł obraz w 1920 r. do Warszawy. Tam został on umieszczony w kaplicy Gimnazjum Towarzystwa Oświatowego im. Cecylii Plater-Zyberk, przy ul. Pięknej $24^{1}$.

W 1928 r. zawiązał się w Warszawie Komitet Budowy Kaplicy Kresowej, którego członkowie wywodzili się ze środowisk kresowych. Członkowie Komitetu postawili przed sobą zadanie zbudowania kaplicy przy nowo wznoszonym kościele pw. Niepokalanego Poczęcia NMP, w parafii pw. św. Jakuba w Warszawie. Była ona projektowana z myślą o przeniesieniu do niej obrazu Matki Bożej Latyczowskiej, by - w miejscu dostępnym dla ogółu wiernych - nie został on zapomniany. Kaplica miała być pokryta polichromią, a od reszty kościoła planowano odgrodzić ją kratą z brązu. W 1930 r. były już zamówione witraże².

Tymczasem 19 grudnia 1930 r., bez wiedzy członków Komitetu Budowy Kaplicy Kresowej, obraz Matki Bożej Latyczowskiej został zabrany z miejsca jego dziesięcioletniej lokalizacji i wywieziony na Wołyń. O tym, jak wielkie emocje wywołał fakt jego ,zniknięcia”, zarówno wśród członków komitetu, jak i w środowiskach kresowych, świadczą pisma członków zarządu tegoż komitetu kierowane po drugiej wojnie światowej do przedstawicieli władz kościelnych w Pol-

* Maria Dębowska - dr hab. historii i archiwistyki, prof. KUL w Ośrodku Archiwów Bibliotek i Muzeów Kościelnych KUL, e-mail: dembo@kul.pl

${ }^{1}$ H. Szumił, Sanktuarium Matki Bożej Latyczowskiej, Sandomierz 1994, s. 49-50.

${ }^{2}$ H.I. Szumił, „Nigdym ja ciebie, ludu, nie rzuciła”. Z dziejów latyczowskiej Ikony, LublinSandomierz 2015, s. 126-129. 
sce z prośbą o umieszczenie obrazu w miejscu dostępnym dla ogółu wiernych ${ }^{3}$. „Decyzja sprzeciwu ze strony ks. bpa Szelążka - jak napisali 16 lipca 1945 r. członkowie Prezydium Komitetu Budowy Kaplicy Kresowej do ks. Stanisława Mystkowskiego, proboszcza parafii pw. św. Jakuba w Warszawie - pokrzyżowała plany Komitetu dotyczące Cudownego Obrazu Matki Bożej Latyczowskiej"4. Biskup Szelążek został nawet oskarżony o „dokonanie raptu”:

Mające już niebawem nastąpić przeniesienie Cudownego Obrazu Latyczowskiego do przeznaczonej dlań kaplicy przekreślił nieoczekiwanie J.E. Ks. Bp Adolf Szelążek, ordynariusz łucki. Jednego wieczoru zgłosiło się z jego polecenia dwóch księży na Piękną 24 i, pomimo protestu J.E. Ks. Arcybiskupa Roppa $^{5}$, „Obraz” został przez nich zabrany i przewieziony następnie do Łucka. J.E. Bp Szelążek miał przez Rzym zleconą sobie pieczę nad znajdującymi się bez opieki przedmiotami kultu z kresów pochodzącymi, chciał spalony ponoć w czasie I wojny światowej obraz Matki Bożej z głównego ołtarza łuckiej katedry zastąpić6 , lecz to bynajmniej nie thumaczy dokonanego przezeń raptu"7.

\section{Przewiezienie obrazu do Lubomla w diecezji łuckiej}

Wywiezienie obrazu Matki Bożej Latyczowskiej z Warszawy na Wołyń wszyscy badacze uzasadniają - jak dotychczas - wyłącznie decyzją ordynariusza łuckiego bpa Adolfa Piotra Szelążka, który miał zleconą przez Stolicę Apostolską opiekę nad mieniem kościelnym wywiezionym do Polski z terenów diecezji kamienieckiej ${ }^{8}$. Istotnie, bp Szelążek wydał zarządzenie o konieczności przekazywania mu wszelkich przedmiotów ze wspomnianej diecezji ${ }^{9}$. Na mocy tegoż

${ }^{3}$ Korespondencja Komitetu Budowy Kaplicy Kresowej została opublikowana przez A. Wolińską-Wójtowicz, Matka Boża Latyczowska, Lublin 2014, s. 56-72.

${ }^{4}$ Tamże, s. 58.

${ }^{5}$ Arcybiskup mohylewski Edward Ropp, po przybyciu do Polski w 1919 r., zamieszkał w Warszawie, przy ul. Pięknej 24, w budynku gimnazjum Cecylii Plater-Zyberk. Był kapelanem niehabitowych sióstr ze Zgromadzenia Posłanniczek Najświętszego Serca Jezusowego, które prowadziły Gimnazjum im. Cecylii Plater-Zyberk. A. Kozyrska, Arcybiskup Edward Ropp. Życie i działalność (1851-1939), Lublin 2004, s. 185, 235.

${ }^{6}$ Wielki ołtarz w katedrze łuckiej spalił się 13 grudnia $1924 \mathrm{r}$.

${ }^{7}$ Wolińska-Wójtowicz, Matka Boża Latyczowska, s. 63-64 - Straż przy Cudownym Obrazie Matki Bożej Latyczowskiej do prymasa Stefana Wyszyńskiego, Warszawa, 15 III 1957 r.

8 „Miesięcznik Diecezjalny Łucki” (dalej: MDŁ), 1 (1926) nr 1, s. 21 - „Stolica Apostolska powierzyła J.E. Ks. Biskupowi Adolfowi Szelążkowi funkcję Administratora Apostolskiego w stosunku do osób, spraw i rzeczy Diecezji Kamienieckiej i Żytomierskiej w granicach Rzeczypospolitej Polskiej".

${ }^{9}$ Biskup A. P. Szelążek do „Wielebnego Duchowieństwa Diecezji Kamienieckiej na terenie Rzeczypospolitej Polskiej”, Łuck, 21 V 1927 r. - „Dążąc do spełnienia, włożonych na mnie przez Stolicę Apostolską obowiązków, zmuszony jestem przystąpić obecnie do zebrania pod swój bezpośredni nadzór wszystkich przedmiotów, należących do Diecezji Kamienieckiej, uratowanych i wywiezionych z Bolszewii, a pozostawających obecnie na terytorium Rzeczypospolitej Polskiej. Na podstawie dostarczonych mi informacji, znane mi są pewne przedmioty, stanowiące własność wspomnianej diecezji, a przechowywane w Polsce. Wykaz wszakże tych rzeczy nie jest dokładny. Pozostawienie tych rzeczy w obecnym ich rozproszeniu na terytorium Polski, może doprowadzić do 
swojego uprawnienia, ale w porozumieniu z władzami kościelnymi archidiecezji warszawskiej, sprowadził obraz do diecezji łuckiej w $1930 \mathrm{r}$.

Nasuwa się jednak od razu pytanie, dlaczego bp Szelążek nie uczynił tego wcześniej - wszak już w lutym 1926 r. objął rządy w diecezji łuckiej. Jak się wydaje, odpowiedź na to pytanie wiąże się z osobą ks. Mariana Tokarzewskiego, kapłana diecezji kamienieckiej. Od 1920 r. przebywał on w Polsce. Po opuszczeniu swojej diecezji, otrzymał nominację na etatowego kapelana kadry Marynarki Wojennej w Toruniu (5 lipca 1920 r.) oraz Portu Wojennego w Modlinie (od 7 lipca 1920 r.). Dnia 8 listopada 1920 r. został kapelanem Naczelnika Państwa Józefa Piłsudskiego (25 października 1921 r. w Pałacu Belwederskim pobłogosławił związek małżeński Józefa Piłsudskiego i Aleksandry Szczerbińskiej). W 1923 r. został kapelanem prezydenta Stanisława Wojciechowskiego; po przewrocie majowym 1926 r. zrzekł się tej funkcji. Kolejne cztery lata pracował w archidiecezji warszawskiej. Od 15 listopada 1926 r. był proboszczem parafii pw. św. Anny w Grodzisku Mazowieckim. Następnie w okresie od 1 lipca 1929 r. do 27 kwietnia 1930 r. sprawował funkcję proboszcza parafii pw. św. Michała Archanioła w Nowym Dworze Mazowieckim. W 1930 r. ks. Tokarzewski przeniósł się na stałe do diecezji łuckiej. Jednak do końca życia (stracił je najprawdopodobniej w 1941 r.) należał do diecezji kamienieckiej. Po przybyciu do Łucka, od 5 maja 1930 r. zamieszkał $\mathrm{w}$ gmachu łuckiego seminarium duchownego na przedmieściu Krasne. Wykładał homiletykę i teologię pastoralną w seminarium duchownym. Był także członkiem Sekcji Nauki i Sztuki w łuckiej Kurii Diecezjalnej. W 1930 r. bp Szelążek powierzył mu przeprowadzenie akcji zbierania funduszów na budowę kościołów na Wołyniu ${ }^{10}$.

Dnia 19 grudnia 1930 r. obraz Matki Bożej Latyczowskiej został zabrany z Warszawy, przewieziony koleją do Lubomla i umieszczony w tamtejszym - najstarszym na Wołyniu - kościele parafialnym pw. Trójcy Świętej (fundacja z 1412 r.). Jak się wydaje, stało się to nieprzypadkowo już w kilka miesięcy po przeniesieniu się ks. Tokarzewskiego do Łucka. Być może, dopiero wtedy dowiedział się on o zamiarze zbudowania nowego wielkiego ołtarza w katedrze łuckiej. po doszczętnym zniszczeniu starego w pożarze z 1924 r. Spalił się wówczas słynący łaskami obraz Matki Bożej „Dominikańskiej”, a Łuck przestał być miejscem pielgrzymkowym. To prawdopodobnie ks. Tokarzewski podsunął bpowi Szelążkowi

zatarcia pamięci o nich i do utraty ich dla Diecezji Kamienieckiej. Dla uchronienia przed tą ewentualnością, winny być podjęte odpowiednie zapobiegawcze środki. Koniecznym jest dostarczenie mi jak najściślejszych wskazówek w danym przedmiocie przez Wielebnych Kapłanów Diecezji Kamienieckiej. Polecam nadesłanie mi jak najspieszniej i nie później niż do dnia 10 czerwca b.r. ścisłych wyjaśnień o tym, jakie przedmioty kościelne, parafialne itd., według posiadanych przez Wielebnych Księży wiadomości, wywiezione zostały z Diecezji Kamienieckiej i gdzie zostały ulokowane. O ile Wielebni Księża posiadają pod swoją opieką tego rodzaju przedmioty, należy je natychmiast dostarczyć do Łucka, do mojej Kurii. Dostarczyć należy także wszelkie dokumenty, dotyczące ulokowania omawianych przedmiotów oraz inne dokumenty i książki, stanowiące własność Diecezji Kamienieckiej lub instytucji kościelnych”, MDŁ, 2 (1927) nr 6, s. 420-421.

${ }^{10}$ M. Dębowska, L. Popek, Duchowieństwo diecezji tuckiej. Ofiary wojny i represji okupantów 1939-1945, Lublin 2010, s. 158-159. 
pomysł sprowadzenia do Łucka obrazu Matki Bożej Latyczowskiej ${ }^{11}$, by - jak napisał korespondent „Życia Katolickiego”:

pod niejednym względem zagrożony Wołyń pozyskał mocną obronę w postaci Cudownego Obrazu, historycznie związanego z Kresami, oraz by pod wpływem pobożnych pielgrzymek do Obrazu wzmogła się gorliwość ludu naszego, zewsząd narażonego na zgubne wpływy ${ }^{12}$.

Można $\mathrm{z}$ dużą dozą prawdopodobieństwa przyjąć, iż spiritus movens tego przedsięwzięcia był właśnie ks. Tokarzewski, a nie bp Szelążek. Przebywając przez dziesięć lat w Warszawie lub w jej okolicach, ks. Tokarzewski miał z pewnością bardzo dobre i częste kontakty z tamtejszymi środowiskami kresowymi. Wiedział o budowie Kaplicy Kresowej z przeznaczeniem dla obrazu Matki Bożej Latyczowskiej. Ze względu na to, że po ukończeniu budowy kaplicy i przeniesieniu do niej obrazu, wydostanie go stamtąd nie wchodziłoby już w rachubę - z czego ks. Tokarzewski musiał zdawać sobie sprawę - należało działać szybko. Do problemów, które należało wówczas wziąć pod uwagę, należały: z jednej strony wielki ołtarz $\mathrm{w}$ katedrze łuckiej, niedostosowany do natychmiastowego umieszczenia $\mathrm{w}$ nim obrazu, a $\mathrm{z}$ drugiej - prawdopodobny sprzeciw środowisk kresowych. Aby nie tracić cennego czasu, zdecydowano się na natychmiastowe zabranie obrazu z Warszawy i umieszczenie go w jednym z kościołów na terenie diecezji łuckiej, do czasu przygotowania odpowiedniego dlań miejsca w katedrze łuckiej. Wybór padł na Luboml. Był tam najstarszy kościół na Wołyniu, a jednocześnie miasto znajdowało się na trasie z Warszawy do Lucka. Natomiast, zarówno Komitet Budowy Kaplicy Kresowej, jak i środowiska kresowe nie zostały o tym fakcie poinformowane.

Dnia 19 grudnia 1930 r. trzej duchowni, przedstawiciele bpa Szelążka (jednym z nich był ks. Tokarzewski), zabrali obraz z Warszawy i koleją dotarli z nim do Lubomla. Biskup Szelążek, pismem z 14 grudnia 1930 r. (№ 6595), zlecił opiekę nad obrazem ks. Stefanowi Jastrzębskiemu, proboszczowi lubomelskiemu i jednocześnie dziekanowi dekanatów lubomelskiego i kowelskiego:

Niniejszym powierzamy Przewielebnemu Księdzu Dziekanowi opiekę nad Obrazem Matki Boskiej Latyczowskiej, po odebraniu go z rąk Naszego Delegata Jaśnie Wielmożnego Księdza Prałata Mariana Tokarzewskiego, profesora Seminarium Duchownego w Łucku, a to do czasu, dopóki ten Obraz nie będzie mógł być przeniesiony do katedry Naszej w Łucku. Mamy to przekonanie, iż ten Obraz Cudowny będzie w Lubomlu otoczony należną opieką i czcią największą ${ }^{13}$.

${ }^{11}$ H. Szumił jest zdania, że to „obywatele Podola i Wołynia, na czele ze Stanisławem Kownackim, osiadłym na Wołyniu obywatelem latyczowskim, uważali, że miejsce Cudownego Obrazu jest na Kresach i zwrócili się do bpa Adolfa Piotra Szelążka, ordynariusza diecezji łuckiej, z prośbą o sprowadzenie Obrazu na Wołyń”. Szumił, Sanktuarium Matki Bożej Latyczowskiej, s. 51; taż, ,Nigdym ja ciebie, ludu, nie rzucita", s. 130.

${ }^{12}$ Podola Pani wróciła na Kresy, „Życie Katolickie”, 2 (1931) nr 1, s. 3.

${ }^{13}$ Kościół Lubomelski, wstęp i oprac. M. Dębowska, Lublin 2015, s. 57. 
Dopiero w kilka dni później - 26 grudnia 1930 r. - katolicy z parafii lubomelskiej i parafii okolicznych mogli uroczyście powitać obraz ${ }^{14}$, umieszczony w wielkim ołtarzu kościoła w Lubomlu. W czasie pobytu w kościele lubomelskim obraz był zasłaniany ,ciemno-złocistą zasłoną”, a przy jego odsłanianiu „grano zawsze pobudkę na klarnecie i uderzano w gong i kocioł" ${ }^{15}$. Przewidywano, że pozostanie on w Lubomlu najwyżej kilka miesięcy - do wiosny 1931 r., kiedy to

z nastaniem pory odpowiedniej wyruszy Obraz Cudowny w uroczystej procesji do Łucka, zatrzymując się w możliwie największej liczbie kościołów parafialnych, by jak najwięcej wiernych mogło uczcić Panienkę Najświętszą i z łask, przez Nią obficie wyjednywanych, skorzystaćl ${ }^{16}$.

Tymczasem mijały kolejne wiosny, a obraz wciąż był w Lubomlu; pozostał tam aż do 1935 r. Ówczesny jego opiekun ks. Stefan Jastrzębski, proboszcz lubomelski, odpowiedzialny za bezpieczeństwo obrazu, musiał zadbać, by nie doznał on najmniejszego uszczerbku. Co mogło zagrażać bezpieczeństwu obrazu w Lubomlu? Na to pytanie znajdujemy odpowiedź w pismach bpa Szelążka, kierowanych do ks. Jastrzębskiego. Kresowiacy z Komitetu Budowy Kaplicy Kresowej w Warszawie, dowiedziawszy się, gdzie obraz został umieszczony, najprawdopodobniej zamierzali go odzyskać uciekając się nawet do gwałtownych metod, bo czym można wytłumaczyć niepokój bpa Szelążka, który w piśmie z 10 lutego 1931 r. przestrzegał proboszcza lubomelskiego:

powiadamiam Najdrożzzego Księdza Dziekana, że, według kursujących w Warszawie wieści, p. hr. Grocholski ${ }^{17}$ ma podjąć energiczne starania celem powrotnego przewiezienia Cudownego Obrazu N.M.P. do Warszawy - a jeśli te starania spełzną na niczym, wówczas Nasz Cudowny Obraz ma być wykradziony. Piszę o tym poufnie. Proszę zatem otoczyć wielką opieką i czujnością kościół, aby ustrzec się przed wszelkimi niebezpieczeństwami ${ }^{18}$.

Po otrzymaniu od bpa Szelążka informacji o możliwości wykradzenia obrazu, ks. Jastrzębski odnotował: „uspokoiłem Pasterza, że czujność wzmożona” dodając: „widać, jak Najdostojniejszy Pasterz troszczył się o całość Cudownego Obrazu"19.

${ }^{14}$ Podola Pani wróciła na Kresy, s. 3-4.

${ }^{15}$ Kościót Lubomelski, s. 59-60.

${ }^{16}$ Podola Pani wróciła na Kresy, s. 3. Księża z dekanatów kowelskiego i lubomelskiego, zebrani w Kowlu na konferencji dekanalnej (19 lutego 1931 r.), zaproponowali, „by obraz niesiono z Lubomla wprost do Łucka i nie zbaczać z drogi”. Konferencje duchowieństwa dekanatów kowelskiego i lubomelskiego diecezji łuckiej, wprowadzenie i oprac. M. Dębowska, Lublin 2015, s. 50.

${ }^{17}$ Bp Szelążek miał na myśli hrabiego Zdzisława Grocholskiego z Pietniczan koło Winnicy. W domowej kaplicy Grocholskich w Pietniczanach został ukryty obraz Matki Bożej z Latyczowa w końcu 1917 r., wówczas, gdy na Ukrainie, pod wpływem rewolucji bolszewickiej w Rosji, rozlała się fala napadów, organizowanych przez chłopów ukraińskich żądnych łatwego wzbogacenia się, Szumił, Sanktuarium Matki Bożej Latyczowskiej, s. 46-47.

${ }^{18}$ Kościół Lubomelski, s. 62.

${ }^{19}$ Tamże. 
Zaniepokojenie bpa Szelążka budziła również możliwość włamania się do kościoła w Lubomlu i kradzieży cennych koron i sukienek z obrazu. Dlatego też, 14 stycznia 1931 r. napisał do ks. Jastrzębskiego:

Zwrócono uwagę, że niegdyś w Latyczowie, w chwilach pewnych niebezpieczeństw zdejmowano z Obrazu Matki Boskiej korony i sukienkę metalową i przechowywano je w skarbcu pod największą ochroną. Czy obecnie, gdy dzieją się $\mathrm{w}$ rozmaitych miejscowościach śmiałe kradzieże, nie należałoby również tego uczynić? ${ }^{20}$

Jak się jednak okazało, obraz w kościele lubomelskim znajdował się pod szczególną ochroną, zarówno parafian lubomelskich, jak i policji państwowej, która miała swój posterunek w Lubomlu. Ochrona kościoła musiała być na tyle wystarczająca, że nie zdecydowano się na zdjęcie z obrazu koron i sukienek ${ }^{21}$. Ksiądz Jastrzębski mógł więc uspokoić biskupa:

Odpisałem Najdostojniejszemu Pasterzowi, że 2 parafian zawsze czuwa nad kościołem. Posterunek policji państwowej otrzymał zarządzenie co godzina być przy kościele w nocy22.

Biskup Szelążek podziękował za troskę lubomelskiej wspólnoty parafialnej o bezpieczeństwo obrazu w piśmie z 12 listopada 1935 r., skierowanym do ks. Jastrzębskiego w związku z przewiezieniem ikony do Łucka:

Jednocześnie uważamy za swój obowiązek złożenie najgorętszej podzięki Jaśnie Wielmożnemu Księdzu Kanonikowi za staranną opiekę nad tym Obrazem. Podobnież ludności katolickiej parafii lubomelskiej za poświęcenie, z jakim służyła temu Obrazowi, wystawiając w ciągu kilku lat stróże dla jego ochrony, za pobożność także, jaką pielęgnuje w swych duszach czcząc Najświętszą Maryję Pannę̨23.

Nie posiadamy świadectw o tym, iż w czasie pobytu w kościele lubomelskim przybywały tam pielgrzymki z parafii diecezji łuckiej, znajdujących się w bliższej lub dalszej odległości od Lubomla. Nie wspominali też nic o tym duchowni dekanatów kowelskiego i lubomelskiego, zbierający się cztery razy do roku na konferencje dekanalne w Kowlu. Być może, wymienione powyżej zagrożenia nie pozwalały na szerzenie kultu właśnie w tym miejscu. Przy obrazie w kościele lubomelskim nie umieszczono nawet wotów przywiezionych razem z nim z Warszawy ${ }^{24}$. Niemniej jednak, proboszcz lubomelski w pewien sposób zadbał o uwiecznienie faktu przebywania ikony Matki Bożej Latyczowskiej w jego ko-

\footnotetext{
${ }^{20}$ Tamże, s. 61.

${ }^{21}$ Tamże.

${ }^{22}$ Tamże.

${ }^{23}$ Tamże, s. 64.

${ }^{24}$ „Łącznie z Obrazem mają być Naszym Delegatom [przewożącym w 1935 r. obraz z Lubomla do Łucka - M.D.] doręczone wota, które - według pisma Jaśnie Wielmożnego Księdza Kanonika z d. 20 stycznia 1931 roku, L. 82 - pozostają w przechowywaniu Jaśnie Wielmożnego Księdza Kanonika" (Stefana Jastrzębskiego), tamże.
} 
ściele, gdyż polecił wydrukowanie obrazka o tym informującego ${ }^{25}$. Sam bp Szelążek prosił o przysłanie mu pewnej ich liczby.

Wydaje się jednak, że nie chciano zbytnio nagłaśniać faktu przebywania obrazu przez kilka lat w kościele lubomelskim. W broszurce, opublikowanej przez drukarnię Kurii Diecezjalnej w Łucku w pierwszych miesiącach po umieszczeniu obrazu w wielkim ołtarzu katedry łuckiej, nie ma o tym najmniejszej wzmianki. Jej anonimowy autor informuje tylko, iż „Najprzewielebniejszy Arcypasterz sprowadził dnia 18 listopada 1935 r. do katedry łuckiej najcenniejszy skarb tej diecezji" - kamienieckiej ${ }^{26}$. Nie można przesądzać, iż świadczy to o zacieraniu śladów pobytu ikony w Lubomlu. Prawdopodobnie chodziło wówczas raczej o nienagłaśnianie tego okresu w historii kultu Matki Bożej w obrazie z Latyczowa.

\section{Przeniesienie obrazu do katedry w Lucku}

Nie został zrealizowany początkowy zamysł procesyjnego przeniesienia ikony z Lubomla do łuckiej katedry z odwiedzaniem kościołów parafialnych, znajdujących się w bezpośredniej bliskości drogi do Łucka. Należy zdecydowanie podkreślić, iż fakt zabrania obrazu z kościoła w Lubomlu i przewiezienia go do Łucka został starannie ukryty i to nie tylko przed wiernymi, ale także przed duchowieństwem, nawet tym $\mathrm{z}$ dekanatu lubomelskiego. O pośpiechu widocznym w wydaniu decyzji dotyczącej jego przeniesienia do katedry w Łucku oraz utajnieniu tego faktu, przesądziły najprawdopodobniej wieści z Warszawy, które dotarły do $\mathrm{Lucka}^{27}$, a mianowicie fakt skierowania przez Komitet Budowy Kaplicy Kresowej do nuncjusza apostolskiego w Polsce Franciszka Marmaggiego „obszernego memoriału” - opatrzonego podpisami czterech tysięcy Kresowian w sprawie powrotu obrazu Matki Bożej Latyczowskiej do Warszawy ${ }^{28}$. Wprawdzie nie jest jeszcze dotychczas znana treść tego memoriału, należy jednak przypuszczać, iż właśnie fakt przedłożenia go nuncjuszowi zadecydował o wydaniu przez bpa Szelążka dekretu o natychmiastowym i utajnionym przewiezieniu obrazu do Łucka, mimo iż nowy wielki ołtarz w katedrze łuckiej nie był jeszcze zbudowany, a nawet prace przy nim - zapewne z braku funduszów - zostały wstrzymane.

Dnia 12 listopada 1935 r. bp Szelążek wystosował do ks. Stefana Jastrzębskiego pismo, opatrzone klauzulą tajne (№ 7051), z poleceniem przekazania ikony trzem swoim delegatom:

Okoliczności obecne zmuszają Nas do wypełnienia zobowiązania, jakie uczyniliśmy, iż Obraz ten pozostawać będzie w Katedrze Naszej Łuckiej, z zapewnieniem jego przeniesienia do Latyczowa, gdy warunki na to pozwolą. W myśl powyższego, niniejszym polecamy Jaśnie Wielmożnemu Księdzu Kanonikowi przekazać omawiany Obraz Naszym Delegatom: Jaśnie Wielmożnemu Księ-

${ }^{25} \mathrm{U}$ dołu obrazka umieszczony był napis: „Cudowny Obraz N.M.P. Latyczowskiej w kościele lubomelskim na Wołyniu", zob. tamże, s. 66.

${ }^{26}$ Historia Cudownego Obrazu Najświętszej Marii Panny Latyczowskiej znajdującego się w katedrze tuckiej, [Łuck 1936], s. 24.

${ }^{27}$ Być może, bp Szelążek dowiedział się o tym w samej Warszawie, wszak często tam jeździł na posiedzenia rozmaitych komisji Episkopatu Polski.

${ }^{28}$ Wolińska-Wójtowicz, Matka Boża Latyczowska, s. 64. 
dzu Infułatowi Teofilowi Skalskiemu, proboszczowi parafii łuckiej, Przewielebnemu Księdzu Karolowi Gałęzowskiemu, prefektowi gimnazjum łuckiego oraz Przewielebnemu Wicekanclerzowi Naszej Kurii, Księdzu Dr. Tymoteuszowi Szyszkiewiczowi. Przekazanie to ma nastąpić bez żadnej zwłoki, natychmiast po otrzymaniu niniejszego dekretu, z zachowaniem jak największej roztropności, aby sam ten akt przyjęcia Obrazu i odwiezienia go do Łucka nie napotkał na żadne trudności ${ }^{29}$.

Wspomniani wyżej wysłannicy bpa Szelążka zjawili się w Lubomlu 18 listopada i sporządzili protokół przejęcia obrazu w brzmieniu następującym:

Protokół przyjęcia Cudownego Obrazu Najświętszej Maryi Panny Latyczowskiej pozostającej, na mocy dekretu Najdostojniejszego Biskupa Łuckiego Dr. Adolfa Szelążka z dnia 14 grudnia 1930 r. № 6395, na przechowaniu w parafialnym kościele lubomelskim, pod opieką Przewielebnego Księdza Kanonika Stefana Jastrzębskiego, proboszcza i dziekana lubomelskiego. W wykonaniu zarządzenia Ekscelencji Księdza Biskupa Łuckiego z dnia 12 listopada 1935 r. № 7051, wystosowanego do Jaśnie Wielmożnego Księdza Infułata Teofila Skalskiego, proboszcza parafii łuckiej, my niżej podpisani delegaci Jego Ekscelencji Księdza Biskupa Ordynariusza - infułat Teofil Skalski, ksiądz prefekt Karol Gałęzowski i wice-kanclerz Kurii Biskupiej ks. Tymoteusz Szyszkiewicz otrzymaliśmy dnia 18 listopada 1935 r. od Przewielebnego Księdza Dziekana Stefana Jastrzębskiego Cudowny Obraz Matki Boskiej Latyczowskiej $\mathrm{z}$ ramą bagetową i zasłoną z materii koronkowej. Nadto dwie ramy wotów w liczbie i jakości zgadzającej się ze spisem wotów, sporządzonym dnia 19 XII 1930 r. przez Towarzystwo Oświatowe im. Cecylii Plater-Zyberkówny, za wyjątkiem 1 punktu tego spisu, gdzie figurują dwa zegarki srebrne, a okazał się jeden. Oprócz tego, jako ofiara parafii lubomelskiej - dwa srebrne lichtarze wraz z profitkami. Dnia 18 XI 1935 r. $^{30}$

Przewiezienie samochodem obrazu do katedry w Łucku odbyło się bez najmniejszych przeszkód. Jedynie księża z dekanatu lubomelskiego, nieznający kulisów tego przedsięwzięcia, podczas konferencji dekanalnej, odbytej w Lubomlu 12 grudnia 1935 r., dali wyraz swojemu niezadowoleniu z faktu jego utajnienia:

Księża zebrani opowiadali o pewnym bólu ludzi, że nie powiadomiono, kiedy cudowny obraz Najświętszej Maryi Panny zostanie zabrany z Lubomla i nie dano możności ,pożegnać” [...]. Stwierdzono, że uroczyste przeniesienie do katedry spowodowałoby olbrzymie skutki: manifestację religijną, podniesienie ducha itd. ${ }^{31}$

\section{Budowa wielkiego ołtarza w katedrze łuckiej}

Do grudnia 1924 r. w wielkim ołtarzu katedry łuckiej znajdowały się dwa obrazy: w części górnej, w niszy - obraz Trójcy Świętej pędzla Tadeusza Kuntze, pod nim zaś obraz Matki Bożej „Dominikańskiej”. Dnia 13 grudnia 1924 r., w sobotę po nieszporach, po ósmej godzinie wieczorem ,zadzwoniły na trwogę" dzwony przy kościele katedralnym. Spalił się wówczas doszczętnie wielki ołtarz

\footnotetext{
${ }^{29}$ Kościół Lubomelski, s. 63.

${ }^{30}$ Tamże, s. 65.

${ }^{31}$ Konferencje duchowieństwa, s. 101.
} 
z umieszczonymi w nim obrazami ${ }^{32}$. Wcześniej, dzięki obrazowi Matki Bożej, Łuck był miejscem pielgrzymkowym. Po pożarze ruch pielgrzymkowy zamarł.

Do 1926 r. wielki ołtarz w katedrze łuckiej odrestaurowano na tyle, że w jego niszy zawisła rzeźba Chrystusa Ukrzyżowanego. Ten stan traktowano jako rozwiązanie tymczasowe, zamierzając prawdopodobnie przywrócić ołtarzowi pierwotny wygląd. Szczątkowe materiały, jakie zachowały się odnośnie do realizacji tego przedsięwzięcia, nie pozwalają na pełne odtworzenie procesu budowy wielkiego ołtarza w katedrze łuckiej33. Jak się wydaje, aż do 1938 r. prace przy jego odbudowie posuwały się naprzód w tempie prawie ślimaczym. W 1927 r., ówczesny proboszcz parafii katedralnej, ks. Gustaw Jełowicki czynił rozeznanie w sprawie materiałów (marmurów) do budowy ołtarza oraz kosztów z tym związanych ${ }^{34}$.

W początkach lat trzydziestych, a więc już po przewiezieniu obrazu Matki Bożej Latyczowskiej do Lubomla, rozpoczęto intensywniejsze prace. W $1931 \mathrm{r}$. pozyskano Władysława Drapiewskiego, artystę malarza z Pelplina, na wykonawcę projektu wielkiego ołtarza ${ }^{35}$. Jak się wydaje, na tym etapie przygotowań zamierzano przywrócić wielkiemu ołtarzowi poprzedni kształt, z nowymi oczywiście obrazami. Tylko obraz Matki Bożej „Dominikańskiej” zdecydowano się zastąpić ikoną Matki Bożej Latyczowskiej. W niszy wielkiego ołtarza miał zaś znaleźć się po dawnemu obraz Świętej Trójcy. Na nadzwyczajnym posiedzeniu kapituły katedralnej w Łucku, 22 kwietnia 1932 r., poświęconym sprawie budowy wielkiego ołtarza, jej członkowie zadecydowali o ufundowaniu obrazu Trójcy Świętej i powierzeniu tej pracy Władysławowi Drapiewskiemu ${ }^{36}$. Artysta nie zamierzał jed-

${ }^{32}$ Pożar w Kościele Katedralnym w Łucku, „Lud Boży”, 17 (1924) nr 52, s. 424-425.

${ }^{33}$ Teczka zatytułowana „Budowa wielkiego ołtarza”, w zasobie Archiwum Diecezji Łuckiej (dalej: ADŁ) - przechowywana jest obecnie w Ośrodku Archiwów, Bibliotek i Muzeów Kościelnych Katolickiego Uniwersytetu Lubelskiego Jana Pawła II.

${ }^{34} \mathrm{ADE}$, t. Budowa wielkiego ołtarza, s. 1-2.

35 „Ja z mej strony 3-go kwietnia 1931 roku wysłałem do Łucka, razem z projektami ołtarza, także opis sposobu wykonania tego ołtarza i mniej więcej oznaczyłem koszt tych prac", ADŁ, t. Budowa wielkiego ołtarza, s. 3, Władysław Drapiewski do ks. Gustawa Jełowickiego, Płock, 16 V 1932 r.; ,,[...] projekt ołtarza tego jest w Łucku. Wysłany on był, o ile sobie przypominam, w dwóch egzemplarzach - rozwarty i zamknięty, w dniu 3-go kwietnia 1931-go roku do Kurii Biskupiej lub też do Ekscelencji Biskupa Ordynariusza”, tamże, s. 5, Władysław Drapiewski do ks. Gustawa Jełowickiego, Pelplin, 10 VI 1932 r. Władysław Drapiewski zaproponował także firmy, które mogłyby wykonać poszczególne elementy ołtarza: „Podaję więc adresy tych przedsiębiorstw, które ołtarz mogłyby wykonać. Od siebie zaznaczam, że należy cenę dobrze wytargować z firmami, boć kryzys nas do tego zmusza. Zatem: 1) Kamieniarski Zakład Marmurów Kieleckich Firmy Urbański i Sp., Łódź. 2) Główny Zarząd Dóbr Książąt Czartoryskich Kopalni Alabastrów, Lwów (zaznaczam, że w alabastrze mogą być wykonane tylko niektóre części ołtarza). 3) Zakład Ojców Jezuitów, Kraków, Pracownia Stiuków. Tam wyuczeni w tym kunszcie braciszkowie wykonali szereg prac w kościele jezuitów w Krakowie. Sądzę, że udzielą oni bliższych szczegółów co do ceny i sposobu wykonania. Dobrze by było przesłać tym przedsiębiorstwom kopie ołtarza i wprost od nich zażądać kosztorysów", tamże, s. 3-4, Władysław Drapiewski do ks. Gustawa Jełowickiego, Płock, 16 V 1932 r.

${ }^{36}$ ADŁ, t. Protokoły posiedzeń kapituły katedralnej w Łucku (1921-1942), s. 43. 
nak sporządzić kopii spalonego obrazu, ale namalować go według własnej wizji ${ }^{37}$. Celem zebrania potrzebnych mu wymiarów wszystkich obiektów, Władysław Drapiewski zjawił się w Łucku na początku lipca 1932 r. Tutaj - przypuszczalnie z powodu kryzysu gospodarczego - zadecydowano o uproszczeniu projektu ołtarza tak, by koszt jego wykonania był zdecydowanie niższy. Widocznie artysta zgodził się na to, gdyż we wrześniu 1932 r. poprosił o przysłanie mu fotografii obrazu Matki Bożej Latyczowskiej i jego wymiarów, ponieważ do Lubomla, najprawdopodobniej z braku czasu, nie dotarł:

W sprawie ołtarza głównego, to oczywiście do nowego, uproszczonego projektu dotąd nie mogłem przystąpić, bowiem nie nadesłano mi jeszcze najważniejszej rzeczy, to jest fotografii i wymiarów cudownego obrazu Matki Boskiej. Bez tych wymiarów nie mogę nic zrobić. Stanowić on bowiem będzie ośrodek całej kompozycji ołtarza i obrazu nad nim. Zależnie od kształtu i wymiarów cudownego obrazu, zastosuje się także wielkość i kompozycję górnego obrazu Świętej Trójcy. Podczas ostatniej mej bytności w Łucku i omawianiu nowego, tańszego projektu ołtarza, Imć Ksiądz Prałat upewniał mnie, że fotografia i wymiar tego obrazu z Lubomli będzie wysłany pod moim adresem do Pelplina. Dotąd, niestety, ich nie otrzymałem. Byłbym się prędzej o to upomniał, lecz nie wiedziałem, kiedy Imć Ksiądz Prałat do Łucka powróci. Zatem uprzejmie proszę o przesłanie tej fotografii i dokładnych wymiarów obrazu razem z ramą (lub też bez ramy). A skoro będę w posiadaniu tych tak ważnych w tym przypadku wymiarów, natychmiast do wykonania projektów tak ołtarza, jak i obrazu się zabiorę. Wobec tego, że w Łucku jest przedstawicielstwo alabastrowych wyrobów, przy komponowaniu ołtarza wezmę to pod uwagę ${ }^{38}$.

Można przypuszczać, iż tylko na tym zakończyła się współpraca proboszcza parafii katedralnej z Władysławem Drapiewskim. Nie było już dalszej korespondencji (albo się nie zachowała?) między nimi w sprawie wielkiego ołtarza. W księdze rachunkowej parafii katedralnej w Łucku nie zostały odnotowane żadne informacje o zapłacie Drapiewskiemu za jego pracę $e^{39}$. Można więc z tego wnosić, że współpracy nie kontynuowano ${ }^{40}$. Ze względu na brak dokumentów, trudno dociec $\mathrm{z}$ jakiego powodu została ona przerwana.

W 1932 r. parafia katedralna uruchomiła zbiórkę pieniędzy na budowę wielkiego ołtarza w katedrze. Datki spływały do proboszcza, którym wówczas był wciąż jeszcze ks. Gustaw Jełowicki. Kryzys gospodarczy przeszkodził uzyskaniu

37 „Co do obrazu Świętej Trójcy do wielkiego ołtarza, to wyobrażam sobie oczywiście nową zupełnie kompozycję. Obraz ten jest 5,20 metrów wysoki i 2,20 metrów szeroki”, ADŁ, t. Budowa wielkiego ołtarza, s. 6, Władysław Drapiewski do ks. Gustawa Jełowickiego, Pelplin, 10 VI 1932 r.

${ }^{38}$ Tamże, s. 15-16, Władysław Drapiewski do ks. Gustawa Jełowickiego, Skołatowo, poczta Płońsk, 26 IX $1932 \mathrm{r}$.

${ }^{39}$ ADŁ, Księga rachunków Katedry Łuckiej od 1-go stycznia 1937 r., s. 178-179.

${ }^{40}$ Władysław Drapiewski nie zerwał współpracy z duchownymi diecezji łuckiej. W 1934 r. został powołany przez bpa Szelążka na członka Diecezjalnej Rady Artystycznej (Consilium Artisticum Dioecesanum), utworzonej 22 marca 1934 r. w ramach łuckiej kurii diecezjalnej. Pozostał w niej do wybuchu drugiej wojny światowej, Powołanie przez J. E. Ks. Biskupa Dr. Szelą̇ka Rady Artystycznej Diecezjalnej, MDŁ, 9 (1934) nr 4, s. 138. 
większych efektów, gdyż do 1 stycznia 1937 r. zebrano zaledwie 1372 złotych i 6 groszy ${ }^{41}$.

Sprawa budowy wielkiego ołtarza w katedrze łuckiej nie ruszyła naprzód nawet po przeniesieniu obrazu Matki Bożej Latyczowskiej do Lucka w 1935 r. Pomimo tego, że wielki ołtarz był ciągle w stanie przebudowy, obraz został w nim umieszczony od razu po przewiezieniu go do Łucka ${ }^{42}$.

Nowy impuls w omawianej sprawie przyszedł dopiero w 1937 r. Na rok następny były zaplanowane uroczyste obchody pięćdziesięciolecia kapłaństwa ordynariusza diecezji łuckiej bpa Adolfa Piotra Szelążka. Wszelkie inicjatywy w sprawie budowy wielkiego ołtarza przeszły od proboszcza parafii katedralnej na, specjalnie w tym celu utworzony, Komitet Budowy Wielkiego Ołtarza.

Latem 1937 r. ukonstytuowały się dwa komitety obchodów rocznicy pięćdziesięciolecia kapłaństwa bpa Szelążka, która przypadała 26 maja 1938 r. ${ }^{43}$ - „Komitet Ogólny Duchowieństwa” (nazywany „Komitetem Księży”) i „Komitet Ogólny Diecezjalny" 44 .

Komitetowi duchowieństwa przewodniczył sufragan łucki bp Stefan Walczykiewicz ${ }^{45}$. Wyłonione z niego Prezydium Komitetu Wykonawczego stanowili księża: Antoni Jagłowski (rektor seminarium duchownego) - prezes, Jan Szych (kanclerz Kurii Diecezjalnej) i Kazimierz Woźnicki (wykładowca w seminarium duchownym) - wiceprezesi, Tymoteusz Szyszkiewicz (wykładowca w seminarium duchownym) - sekretarz oraz Jan Zagórski (przewodniczący Sekcji Finansowej w Kurii Diecezjalnej) - skarbnik. Oprócz wymienionych duchownych w skład Komitetu Wykonawczego wchodzili ks. Teofil Skalski (proboszcz parafii katedralnej) i ks. Marian Sokołowski (sekretarz generalny Diecezjalnego Instytutu Akcji Katolickiej). W odezwie tegoż komitetu z 15 sierpnia 1937 r., skierowanej do duchowieństwa diecezji łuckiej zawarty jest apel o składanie ofiar „na kupno daru dla Najdostojniejszego Jubilata" ${ }^{46}$.

${ }^{41}$ ADŁ, Księga rachunków Katedry Łuckiej od 1-go stycznia 1937 r., s. 174: „Z roku 1936 na 1 stycznia przeniesiono kwotę ofiar składanych od 15 grudnia 1932 roku ogółem, razem z przekazanymi w innej walucie przez ks. Jełowickiego".

${ }^{42}, 18$ listopada 1935 roku mieszkańcy Łucka witali przybywający do katedry Cudowny Obraz Najśw. Marii Panny Latyczowskiej. Od tego dnia zawisł on w wielkim ołtarzu katedry łuckiej i pozostanie tu, jeśli taka będzie wola Boża, aż do chwili, w której będzie mógł wrócić do dawnej swej siedziby w Latyczowie, znajdującej się obecnie pod panowaniem bolszewików. Diecezja łucka znajduje się tedy przynajmniej w czasowym posiadaniu nader cennego skarbu". N. Maria Panna Latyczowska, „Życie Katolickie”, 6 (1935) nr 50, s. 787.

${ }^{43} \mathrm{~W}$ odezwie komitetu napisano zaś, iż „w miesiącu czerwcu 1938 roku przypada Jubileusz 50-lecia kapłaństwa J. E. Ks. Biskupa D-ra Adolfa Szelążka, naszego Arcypasterza”, ADŁ, Kuria Diecezjalna w Łucku, t. Zarządzenia władz diecezji łuckiej (1921-1939), s. 69.

${ }^{44}$ „Życie Katolickie”, 9 (1938) nr 37, s. 589.

${ }^{45} \mathrm{~W}$ jego skład wchodzili członkowie obydwóch kapituł: katedralnej w Łucku i kolegiackiej w Ołyce, dziekani, a także delegaci poszczególnych dekanatów, księży prefektów, duchowieństwa zakonnego, kapelanów wojskowych oraz przedstawiciele duchowieństwa obrządku wschodniego, „Życie Katolickie”, 9 (1938) nr 37, s. 589.

${ }^{46}$ ADŁ, Kuria Diecezjalna w Łucku, t. Zarządzenia władz diecezji łuckiej (1921-1939), s. 69. 
Komitet Ogólny Diecezjalny składał się ze 196 osób. Wyłoniony został z niego Komitet Wykonawczy i jego Prezydium w składzie: hrabia Aleksander Ledóchowski ze Smordwy - prezes, Kazimierz Lewicki (dyrektor Państwowego Banku Rolnego w Łucku) i Aleksander Rostocki (dyrektor Diecezjalnego Instytutu Akcji Katolickiej) - wiceprezesi, ks. Władysław Bukowiński (rektor Instytutu Wyższej Kultury Religijnej w Łucku) - sekretarz. Komitet Wykonawczy zorganizował 9 sekcji: programową, finansową, organizacyjno-porządkową, pochodową, mieszkaniowo-żywnościową, szkolną, prasową, dekoracyjną i komunikacyjną ${ }^{47}$.

W ramach wspomnianego, ogólnodiecezjalnego komitetu działał również Komitet Budowy Wielkiego Ołtarza, gdyż powstała idea uczczenia jubilata ufundowaniem wielkiego ołtarza w katedrze łuckiej, w którym centralne miejsce miał zajmować obraz Matki Bożej Latyczowskiej ${ }^{48}$. Ołtarz miał być sfinansowany głównie z ofiar zebranych na terenie diecezji łuckiej. Jego budowę wyceniono wstępnie na 60 tysięcy złotych. Celem zebrania potrzebnych funduszów, dla każdej parafii w diecezji łuckiej wydrukowano ,specjalne księgi ofiar wykonane na trwałym papierze płóciennym oraz pamiątkowe obrazki z wizerunkiem Cudownego Obrazu" ${ }^{49}$. Komitet Budowy Wielkiego Ołtarza w katedrze łuckiej miał wręczyć wspomniane „księgi ofiar” jubilatowi, a następnie miały być one „złożone w pięknej szafce na wieczne czasy w skarbcu Katedry" ${ }^{\prime 50}$. Propagowaniem tej akcji i zbieraniem funduszów (także podczas wizyt kolędowych) mieli zajmować się wszyscy proboszczowie. Do nich został skierowany specjalny okólnik z 3 stycznia $1938 \mathrm{r}^{51}$.

W propagowanie akcji gromadzenia funduszów na budowę ołtarza włączył się także tygodnik „Życie Katolickie”. W numerze z 13 lutego 1938 r. redakcja zamieściła apel do czytelników:

chcemy spełnić jedno z najgorętszych życzeń naszego Pasterza, wznieść w odnowionej przezeń katedrze łuckiej wielki ołtarz dla umieszczenia również przezeń sprowadzonego do tej katedry Cudownego Obrazu Najśw. Maryi Panny Latyczowskiej. Rozesłane zostały w tym celu po wszystkich parafiach

${ }^{47}$ „Życie Katolickie”, 9 (1938) nr 37, s. 589; ADŁ, Parafia w Kołkach, t. Zarządzenia, k. 1.

${ }^{48}$ „Prócz [...] Komitetu Księży, zawiązanego w celu uczczenia tegorocznego jubileuszu 50-lecia kapłaństwa J. E. Ks. Biskupa Dra A. Szelążka, Arcypasterza diecezji naszej, powstał równorzędnie drugi Komitet obchodu jubileuszowego złożony z ludzi świeckich. Ten drugi Komitet, jako wyraz hołdu dla Najdostojniejszego Jubilata zamierzył budowę wielkiego ołtarza w Katedrze Łuckiej dla Cudownego Obrazu Najświętszej Maryi Panny Latyczowskiej”, ADŁ, Parafia w Kołkach, t. Zarządzenia, k. 1.

${ }^{49}$ Tamże.

${ }^{50}$ „Należy prosić, aby nazwiska były pisane czytelnie, książki zachowane w największej czystości, gdyż, jak mówi odezwa, będą one przedstawione Najdostojniejszemu Arcypasterzowi, a następnie złożone w pięknej szafce na wieczne czasu w skarbcu Katedry. Przede wszystkim należy bardzo starannie i czytelnie wpisać nazwę swej parafii na wstępnej karcie księgi [...]. Ofiar nie należy podsumowywać na każdej stronie, ale dopiero po zakończeniu całkowitym listy ofiarodawców. Zamknięcie rachunku ma być stwierdzone podpisem Przewielebnego Ks. Proboszcza i pieczęcią parafialną", tamże, k. 1, 7 .

${ }^{51}$ Tamże, k. 1. Okólnik został przygotowany w Sekcji Nauki i Sztuki (№ 38), a podpisał się pod nim ks. Jan Zagórski, wikariusz generalny. 
książki do zbierania ofiar. Choć niewątpliwie z każdej ambony rozlegają się nawoływania do tego, niech jednak i z tej ambony, jaką stanowi nasze pismo, rozlegnie się głos do nich nawołujący. Kto jeszcze ofiary swej złożyć nie zdążył, niech to uczyni co prędzej, niech i innych do tego zachęci. Im rychlej zakończy się zbiórka ofiar, tym łatwiej będzie się zorientować, jakimi środkami się rozporządza i jak może wyglądać przyszły ołtarz. A tyle mamy powodów, aby wyglądał jak najpiękniej, bo to i ołtarz w naszej katedrze, którą uważamy za matkę wszystkich kościołów diecezji i ołtarz dla pomieszczenia tak drogiego skarbu Kościoła, jakim jest Cudowny Obraz Latyczowski, i ołtarz, który ma stanowić pamiątkę 50-lecia kapłaństwa naszego Pasterza, ma być pomnikiem naszej czci i przywiązania do Jego Osoby ${ }^{52}$.

Ponieważ obchody jubileuszowe zaplanowano na wrzesień 1938 r., dlatego też termin ukończenia zbiórki wyznaczono na 20 kwietnia tego roku ${ }^{53}$. Najwyraźniej gromadzenie funduszy nie przebiegało po myśli organizatorów uroczystości jubileuszowych, gdyż zdecydowano się przedłużyć do 10 maja czas jego zakończenia. Tym razem pod odezwą, z 12 kwietnia 1938 r., skierowaną do proboszczów, podpisał się sufragan Stefan Walczykiewicz ${ }^{54}$. Pod koniec kwietnia mógł on już napisać:

Według wiadomości, które doszły do Kurii, w wielu parafiach zbiórka ofiar została zakończoną, osiągając wynik bardzo pomyślny. (Pewna wiejska parafia zebrała 500 zł). Bardzo serdecznie proszę, aby tam, gdzie zbiórka ofiar jeszcze nie została zakończona, Czcigodni Księża Proboszczowie usilnych dołożyli starań celem wzięcia przez ich parafian wybitnego udziału w dziele budowy ołtarza dla Najśw. Maryi Panny Latyczowskiej ${ }^{55}$.

W kolejnym okólniku (z 26 kwietnia 1938 r.) bp Walczykiewicz apelował, by proboszczowie odesłali zebrane fundusze do 10 maja, do Kurii Biskupiej ${ }^{56}$. Można domniemywać, iż organizatorzy uroczystości jubileuszowych przecenili możliwość zebrania tak dużej sumy, jaką zakładali, czyli 60 tysięcy złotych. Zbiórka pieniędzy, w terminie do 10 maja 1938 r., nie przyniosła oczekiwanych rezultatów. W czerwcu bp Walczykiewicz wysłał do Warszawy, do księcia Janusza Radziwiłła, prawdopodobnie wszystko czym wówczas dysponował, a było to tylko 8 tysięcy złotych. Stąd też koszty wykonania ołtarza musiano znacznie obniżyć. Architekt Kazimierz Skórewicz wyliczył je wstępnie w maju na sumę 31 tysięcy złotych.

Członkiem Komitetu Budowy Wielkiego Ołtarza był książę Janusz Radziwiłł z Ołyki. Do komitetu pozyskano także sławnego architekta Kazimierza Skórewi-

${ }^{52}$ C. [ks. Zygmunt Chmielnicki], Nasz dar, ,Życie Katolickie”, 9 (1938) nr 7, s. 97.

${ }^{53}$ ADŁ, Parafia w Kołkach, t. Zarządzenia, k. 1.

${ }^{54}$ „Nawiązując do okólnika z dnia 3 stycznia b.r. № 38, przy którym były przesłane księgi ofiar na budowę wielkiego ołtarza w katedrze łuckiej dla Cudownego Obrazu Najświętszej Maryi Panny Latyczowskiej, najuprzejmiej i serdecznie proszę, aby okres Świąt Wielkanocnych, kiedy wierni liczniej przybywają do kościoła, szczególniej Czcigodny Ksiądz proboszcz wykorzystał do przeprowadzenia zbioru ofiar na cel powyższy. Ostateczny termin zbioru ofiar przedłuża się do dnia 10 maja b.r.", tamże, k. 6 .

55 Tamże, k. 7.

${ }^{56}$ Tamże. 
cza. Stało się to zapewne z inicjatywy księcia Radziwiłła, znającego artystę osobiście, gdyż przeprowadził on w latach 1929-1930 „poważną modernizację części pomieszczeń parterowych pałacu w Nieborowie", który był własnością księcia ${ }^{57}$. Ze względu na to, że zarówno książę Janusz Radziwiłł, jak i Kazimierz Skórewicz przebywali najczęściej w Warszawie, komitet składał się jakby z dwóch części: warszawskiej i łuckiej ${ }^{58}$. W skład „łuckiej” części Komitetu Budowy Wielkiego Ołtarza wchodził z pewnością proboszcz parafii katedralnej; w pierwszych miesiącach 1938 r. ks. Teofila Skalskiego zastąpił na tym stanowisku ks. Marian Sokołowski. Najprawdopodobniej znalazł się w nim także dr Adam Wojnicz. „Warszawski” Komitet odpowiadał za wykonanie projektu, znalezienie odpowiednich wykonawców, nadzorowanie ich pracy i załatwianie z nimi wszelkich spraw finansowych. Wszystkie rachunki podpisywał książę Janusz Radziwiłł. Można przypuszczać, iż pozyskanie architekta Kazimierza Skórewicza miało na celu uczynienie go odpowiedzialnym za stronę artystyczną ołtarza. Wydaje się, że wspomniany architekt wykonał ogólny szkic ołtarza, gdyż ze względu na obciążenie ogromną ilością obowiązków nie był w stanie poświęcić się całkowicie tej pracy, która wymagałaby wielokrotnych wyjazdów do Łucka ${ }^{59}$. Najprawdopodobniej odwiedził Łuck jeden raz - 9 czerwca $1938 \mathrm{r}^{60}$. Być może, to właśnie on polecił architekta Władysława Sawickiego ${ }^{61}$, który dopracował w szczegółach projekt ołtarza i nadzorował jego montaż w Łucku. Wszystkie elementy ołtarza wykonały firmy warszawskie.

Datę 31 maja 1938 r. nosi prowizoryczny kosztorys sporządzony przez Skórewicza, zatytułowany: „Cały kosztorys zsumowany, na ołtarz wielki w katedrze łuckiej" ${ }^{2}$ :

${ }^{57}$ W. Baraniewski, Kazimierz Skórewicz architekt, konserwator, historyk architektury 18661950, Warszawa 2000, s. 180.

${ }^{58}$ Dowodzą tego słowa Władysława Sawickiego: ,[...] proszę tamtejszy Komitet Budowy Wielkiego Ołtarza w Łucku o załatwienie i przyspieszenie mi tej sprawy co do przesłania mi tej sumy [...]. W Warszawie nie mam możności z nikim się porozumieć. J. E. Ks. J. Radziwiłła nie ma, a prof. K. Skórewicz kazał mi się wobec tego z wszystkimi sprawami zwracać do tamtejszego Komitetu", ADŁ, t. Budowa wielkiego ołtarza, s. 111, Władysław Sawicki do ks. Mariana Sokołowskiego, Warszawa, 10 XI $1938 \mathrm{r}$.

${ }^{59}$ Władysław Sawicki był w Łucku 5 razy, co wynika z przedłożonego przez niego rachunku (wystawionego 22 października 1938 r.) Komitetowi Budowy Wielkiego Ołtarza, tamże, s. 107.

${ }^{60}$ Świadczy o tym pokwitowanie o zwrocie kosztów podróży - 64 zł (Warszawa - Łuck, Łuck - Warszawa), potwierdzone przez K. Skórewicza 9 VI 1938 r., tamże, s. 70, 143.

${ }^{61}$ Władysław Sawicki, wraz z Władysławem Kucharskim zdobył IV Nagrodę za projekt grobowca ku czci generała Gustawa Orlicz-Dreszera na Oksywiu w Gdyni, S. Tworkowski, Konkurs na projekt grobowca ku czci generała Gustawa Orlicz-Dreszera na Oksywiu w Gdyni, „Architektura i Budownictwo", 13 (1937) nr 10, s. 351-363. Według projektu Władysława Sawickiego została zbudowana w 1931 r. willa przy ul. Dębowej 6 w Podkowie Leśnej. Jest to przykład architektury w tzw. stylu dworkowym, bliskim prof. Kazimierzowi Skórewiczowi, który zaprojektował w 1922 r. dworek marszałka Józefa Piłsudskiego w Sulejówku, Baraniewski, Kazimierz Skórewicz, s. 147-151.

${ }^{62} \mathrm{AD}$, t. Budowa wielkiego ołtarza, s. 58. 
1) Wszystkie części metalowe, oprócz mechanizmu do przesuwania drzwi, wykonane przez Braci Łopieńskich ${ }^{63}-17000$

2) Roboty kamieniarskie, wykonane przez firmę kamieniarską Jan Fedorowicz $^{64}-8500$

3) Wykonanie dwóch rzeźb w glinie i odlanie w gipsie, rzeźbione przez Trenarowskiego ${ }^{65}$, absolwenta Akademii Sztuk Pięknych - 1500

4) Montaż i drobne dodatki - 2000

5) Przejazdy i porto - 1000

6) Wykonanie szczegółów projektu, szablonów itp. oraz dozór (przez autora projektu $)^{66}-1600$,

W sumie - 31600 .

Pierwsze zachowane dokumenty Komitetu Budowy Wielkiego Ołtarza pochodzą z końca maja 1938 r., co dowodzi, że przygotowania do realizacji tego przedsięwzięcia rozpoczęły się po wstępnym zakończeniu zbiórki pieniędzy. Firmy warszawskie przewidywały realizację zamówienia w okresie trzech miesięcy. Zważywszy na to, że uroczystości związane z jubileuszem bpa Szelążka były zaplanowane na 10 i 11 września 1938 r., musiał być zachowany reżim czasowy. Ale jak to zwykle bywa w podobnych przypadkach - a i w tym nie było inaczej prace wykończeniowe trwały jeszcze późną jesienią 1938 r., a definitywne ich zakończenie przeciągnęło się aż do lata 1939 r.; nie wiadomo, czy przed wybuchem drugiej wojny światowej zostały one doprowadzone do końca ${ }^{67}$.

Dnia 5 listopada 1938 r. Władysław Sawicki napisał do ks. Mariana Sokołowskiego, ówczesnego proboszcza parafii katedralnej w Łucku:

Budową ołtarza byłem zajęty przeszło 7 miesięcy i jeszcze będę. Przypuszczam, że to małe honorarium mi się należy. Piszę to na ręce Przewielebnego Ks. Proboszcza, ponieważ do tego upoważnił mnie prof. Skórewicz. Następnie J. E. Ks. J. Radziwiłła nie ma w ogóle w Warszawie, do którego bym się zwrócił, co zatem idzie, że ołtarz nie może być skończony, ponieważ on jest arbitrem w tej materii i ja z każdym projektem byłem z księciem związany i teraz w ogóle nie mogę dalej działác ${ }^{68}$.

${ }^{63}$ Fabryka Wyrobów z Brązu i Odlewnia Metali Bracia Łopieńscy Spółka z ograniczoną odpowiedzialnością, Warszawa. Fabryka: Hoża 55, Tel. 9.17-89, sklep: Krakowskie Przedmieście 15, tel. 6.21-90.

${ }^{64}$ Fabryka Kamieniarska Jan Fedorowicz, Warszawa, ul. Dzika 21/23, tel. 11-77-96.

${ }^{65}$ Józef Trenarowski (1907-1965) w latach 1931-1938 studiował w Akademii Sztuk Pięknych w Warszawie. Specjalizował się wtedy w tematyce sakralnej, ale jest także współautorem warszawskiego pomnika Braterstwo Broni (tzw. czterech śpiących).

${ }^{66}$ Prof. Skórewicz miał na myśli architekta Władysława Sawickiego.

${ }^{67}$ ADE, t. Budowa wielkiego ołtarza, s. 131, Jan Fedorowicz do ks. Jana Szycha, kanclerza kurii diecezjalnej w Łucku, Warszawa, 18 VIII 1939 r.: „Celem ukończenia robót kamieniarskich przy budowie wielkiego ołtarza w katedrze, uprzejmie proszę o odwrotne powiadomienie, kiedy i w jakim czasie należy przysłać kamieniarza do ukończenia montowania stopni marmurowych".

${ }^{68}$ Tamże, s. 119-120, Władysław Sawicki do ks. Mariana Sokołowskiego, Warszawa, 5 XI 1938 r. 
O tym, jak napięte były terminy dotyczące projektowania i budowy wielkiego ołtarza, świadczy choćby jedno z pism Kazimierza Skórewicza do ks. Mariana Sokołowskiego:

Ponieważ sprawa sum zadatkowanych dla firm zaciągnęła się, a przedsiębiorcy stawiają za warunek termin $3^{\text {ch }}$ miesięcy od dnia otrzymania wymiarów (,robocze rysunki”) prosiłem Pana Sawickiego, aby wyjechał nie czekając na przysłanie pieniędzy Komitetu w Łucku. Wobec powyższego, uprzejmie proszę o łaskawą pomoc w urządzeniu zarysu ołtarza i wydanie mu stu zł, które tu potrącimy z przysłanych, lub pocztą zwrócimy po otrzymaniu 8000 zł ${ }^{69}$. Obecnie każdy dzień jest drogi ${ }^{70}$.

Ostatecznie zdołano ukończyć zasadnicze prace przy budowie ołtarza przed uroczystościami jubileuszowymi. W późniejszych miesiącach kończono jeszcze stopnie do niego.

Wielki ołtarz został odsłonięty 10 września 1938 r. Pierwszą mszę odprawił przy nim jubilat bp Adolf Piotr Szelążek, a ks. Zygmunt Chmielnicki, kanonik kaznodzieja świąteczny kapituły kolegiackiej w Ołyce, „wygłosił w dniu 10 września w katedrze łuckiej kazanie" ${ }^{\text {"11 }}$.

Do budowy wspomnianego ołtarza wykorzystane zostały dwa rodzaje marmuru. Na wykonanie tabernakulum i filungów w antepedium oraz głównej ramy w nastawie, bp Szelążek i architekt Skórewicz wybrali różowy marmur „Verona”. Do wykonania predelli i mensy ołtarzowej użyto tańszego, czarnego marmuru krajowego „Dębnik”72.

Zewnętrzna, główna rama nastawy ołtarzowej (retabulum) o wymiarach $3 \mathrm{~m}$ (wysokość) i 3,20 m (długość) oraz szerokości $66 \mathrm{~cm}$ (okalająca $\mathrm{z}$ trzech stron ramę metalową), wykonana z marmuru („Verona”), została osadzona na predelli - także marmurowej („,Dębnik”) ${ }^{73}$.

W centrum nastawy ołtarzowej znajdował się obraz Matki Bożej Latyczowskiej. Okalały go złocone 64 promienie. Podłoże dla obrazu, otoczonego promieniami, stanowiła atłasowa materia. Obraz umieszczony został wewnątrz ośmiokątnej ramy o wymiarach $2,80 \times 2,25 \mathrm{~m}$, wykonanej z białego metalu. Zamykany był metalową, dwuczęściową kratą (wymiary jednej części: 2,80×1,15 m). Krata składała się $\mathrm{z}$ „ornamentów żelaznych, kutych, piłowanych, części złączeniowe z brązu złoconego, otok krat z konstrukcji żelaznej, obciągniętej białym metalem. Główne motywy kraty okrągłe" ${ }^{\text {" }}$. Na każdej części kraty zostały umieszczone płaskorzeźby w brązie patynowanym, przedstawiające patronów diecezji łuckiej: św. Stanisława Biskupa i Męczennika oraz św. Teresę od Dzieciątka Jezus. Firma

${ }^{69}$ Pieniądze zostały wkrótce wysłane, o czym ks. Sokołowski powiadomił Kazimierza Skórewicza telegramem: „Profesor Skórewicz, ulica 6 Sierpnia 28, Warszawa. Osiem tysięcy jest do podjęcia w środę rano w Banku Rolnym na Nowogrodzkiej. Ksiądz Sokołowski”, a prof. Skórewicz odnotował na nim: „Pieniądze otrzymałem dn. 9 VI 38”, tamże, s. 89.

${ }^{70}$ Tamże, s. 64-65, Kazimierz Skórewicz do ks. Mariana Sokołowskiego, Warszawa, 7 VI 1938 r.

${ }^{71}$ ADŁ, Protokoły posiedzeń kapituły kolegiackiej w Ołyce, s. 138.

${ }^{72} \mathrm{ADE}, \mathrm{t}$. Budowa wielkiego ołtarza, s. 34.

${ }^{73}$ Tamże, s. 40, 42.

${ }^{74}$ Tamże, s. 22. 
Braci Łopieńskich sporządziła także specjalny mechanizm przesuwowy do zamykania kraty. Trójkątna przestrzeń, w czterech rogach marmurowej ramy - pomiędzy nią i ramą metalową - została wypełniona przez umieszczenie tam główek aniołków $\mathrm{z}$ brązu patynowanego ${ }^{75}$.

Na mensie ołtarzowej, na poziomie predelli znajdowało się marmurowe tabernakulum o wymiarach około $65 \times 50 \times 50 \mathrm{~cm}$, wyłożone wewnątrz blachami jednostronnie złoconymi, zamykane drzwiczkami z rzeźbionym, złoconym motywem.

W zwieńczeniu nadstawy ołtarzowej umieszczony był monogram (M) z krzyżem. Te dwa elementy o wymiarach $1,60 \times 2,20 \mathrm{~m}$, zostały wykonane $\mathrm{z}$,żelaza kutego, grafitowanego, złoconego i srebrzonego płatkowo" 76 .

Tylko przez okres dziesięciu lat (1935-1945) obraz Matki Bożej Latyczowskiej znajdował się w katedrze łuckiej. W kilka miesięcy po zakończeniu drugiej wojny światowej, 6 sierpnia 1945 r. został on w tajemnicy wywieziony z Łucka przez opuszczających Wołyń członków łuckiej kapituły katedralnej i niehabitowe zakonnice ze Zgromadzenia Służek NMP Niepokalanej. Obraz znalazł ostateczną przystań w Lublinie. Przez kilkadziesiąt lat przebywał w kaplicach służek - najpierw przy ul Bernardyńskiej 3 (1945-1984), następnie przy ul. I Armii Wojska Polskiego 9 (1984-2014) ${ }^{77}$. W 2014 r. ikona Matki Bożej Latyczowskiej została przeniesiona do kościoła pw. Matki Bożej Różańcowej, usytuowanego przy ul. Bursztynowej w Lublinie ${ }^{78}$.

Słowa kluczowe: Matka Boża Latyczowska, Łuck, katedra łucka, Luboml

\section{BIBLIOGRAFIA}

Baraniewski Waldemar, Kazimierz Skórewicz architekt, konserwator, historyk architektury 1866-1950, Warszawa 2000.

Dębowska Maria, Popek Leon, Duchowieństwo diecezji łuckiej. Ofiary wojny i represji okupantów 1939-1945, Lublin 2010.

Historia Cudownego Obrazu Najświętszej Marji Panny Latyczowskiej znajdującego się w katedrze łuckiej, [Łuck 1936].

Konferencje duchowieństwa dekanatów kowalskiego i lubomelskiego diecezji łuckiej, wprowadzenie i oprac. Maria Dębowska, Lublin 2015.

Kozyrska Antonina, Arcybiskup Edward Ropp. Życie i działalność (1851-1939), Lublin 2004.

Kościół Lubomelski, wstęp i oprac. Maria Dębowska, Lublin 2015.

Szumił Halina, Sanktuarium Matki Bożej Latyczowskiej, Sandomierz 1994.

75 Tamże.

76 Tamże.

${ }^{77}$ Szumił, ,Nigdym ja ciebie, ludu, nie rzuciła”, s. 161-178.

${ }^{78}$ Ten rozdział w dziejach obrazu Matki Bożej Latyczowskiej obszernie omówiła H.I. Szumił, „Nigdym ja ciebie, ludu, nie rzuciła”, s. 179-215. 
Szumił Halina Irena, „Nigdym ja ciebie, ludu, nie rzuciła”. Z dziejów latyczowskiej Ikony, Lublin-Sandomierz 2015.

Tworkowski Stefan, Konkurs na projekt grobowca ku czci generała Gustawa Orlicz-Dreszera na Oksywiu w Gdyni, „Architektura i Budownictwo”, 13 (1937) nr 10, s. 351363.

Wolińska-Wójtowicz Agnieszka, Matka Boża Latyczowska, Lublin 2014.

\title{
THE IMAGE OF OUR LADY OF LATYCZÓW IN THE DIOCESE OF LUCK
}

\begin{abstract}
Summary
In 1920, the Poles withdrew from Podole under the pressure of Bolshevik army. Leaving Latyczów with the Polish army, the local parish priest took the miraculous image of Our Lady of Latyczów. For ten years it was in the chapel of the middle school of Cecylia Plater-Zyberkówna Educational Society in Warsaw. In 1930, the Bishop of Łuck Adolf Piotr Szelążek decided to transfer it to the Diocese of Łuck. As the high altar in the Cathedral of Łuck had not been adapted to the image yet, it was placed for a few months in the parish church of Luboml. The image was in Luboml for several years, longer than it had been expected. Only at the end of 1935, after receiving disturbing news from Warsaw, Bishop Szelążek ordered to transport it secretly to Lutsk and hang it in the high altar, which had not been ready yet. The new high altar in the Cathedral Church of Luck was ready only for the celebration of the fiftieth anniversary of Bishop Szelążk's priesthood (10-11 September 1938). It was designed probably by an architect from Warsaw, prof. Kazimierz Skórewicz, and another architect - Władysław Sawicki - improved some details and oversaw its installation in the Cathedral of Łuck. The image of Our Lady of Latyczów was in the Cathedral of Łuck for ten years. A few months after the end of World War II, on 6 August 1945, it was secretly deported from Łuck by the members of the Cathedral Chapter of Łuck and non-habited nuns of the Congregation of the Sisters Servants of Mary Immaculate, who were leaving Volhynia. Finally, the image found a haven in Lublin. For several years it was in the chapels of the Sisters Servants - first at 3 Bernardyńska Street (1945-1984), then at 9 I Armii Wojska Polskiego Street (1984-2014). Since 2014 the image has been worshiped in the Church of Our Lady of the Rosary in Bursztynowa Street.
\end{abstract}

Keywords: Our Lady of Latyczów, Łuck, the Cathedral of Łuck, Luboml 


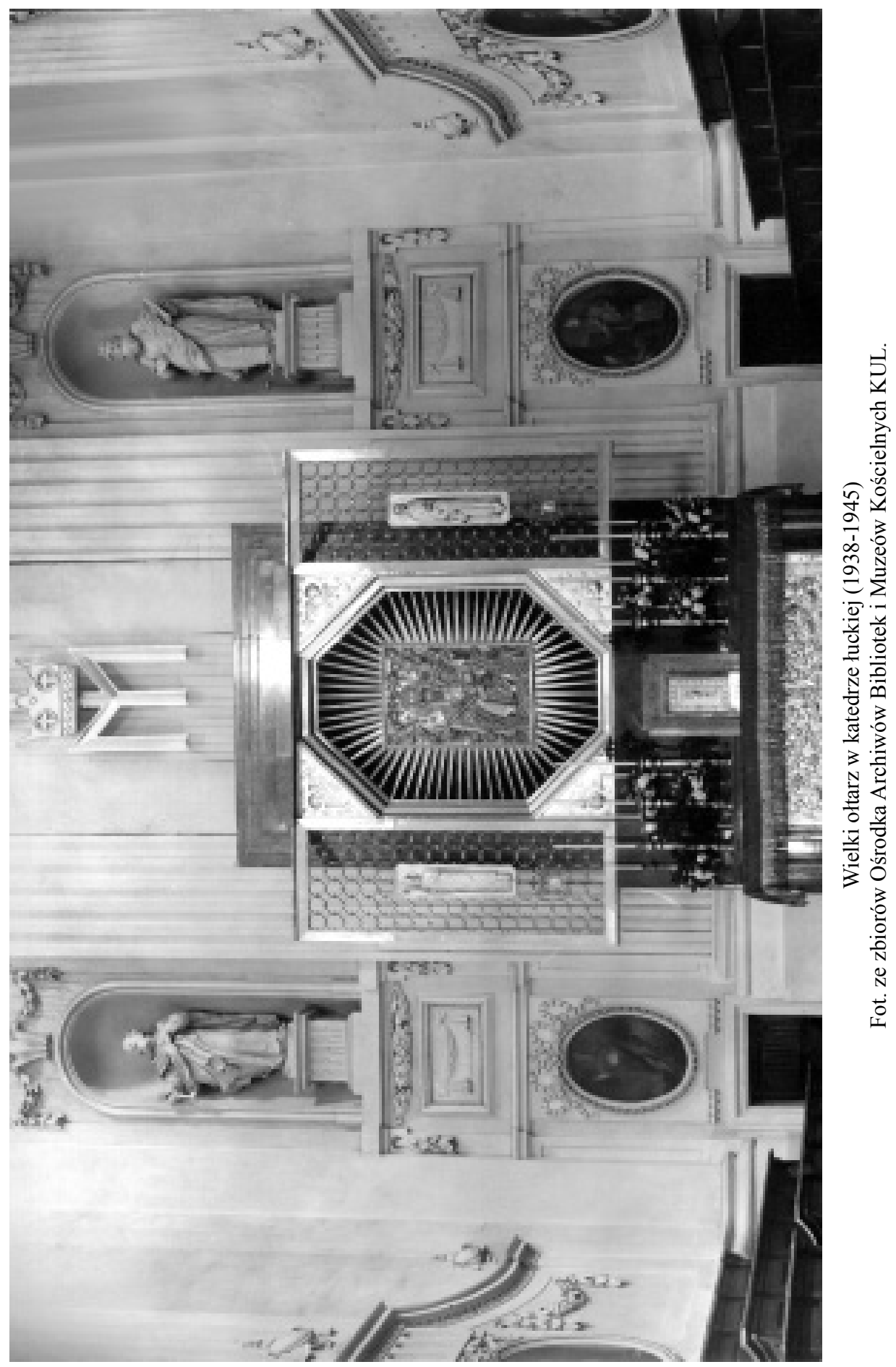

